\title{
MULTI ATTRIBUTE ASSESSMENT APPROACH IN VEGETABLE PRODUCTION
}

\author{
Grujica Vico ${ }^{1}$, Aleksandra Govedarica-Lučić2 ${ }^{2}$ Zoran Rajič3 ${ }^{3}$ Radomir Bodiroga ${ }^{4}$, \\ Ivan Mičićc, Silvija Zec Sambol ${ }^{6}$, Marija Mičićc ${ }^{7}$
}

\section{Summary}

Two types of economic effectiveness and two types of economic efficiency, as well as three types of indicators as nutritional quality criteria were used in this paper for ranking certain winter lettuce growing technologies. Four certain types of growing technologies of winter lettuce in greenhouses were ranked by two multi-attribute decision making methods. Results of ranking for both methods, SAW and TOPSIS are shown. Alternatives were ranked by three different scenarios with different weight coefficients. The type of growing technology with combination of mulching + agro textile is the best ranked one according both methods and all scenarios.The SAW method showed more sensitivity on weight coefficients changes than TOPSIS.

Key words: multi-attribute ranking, SAW, TOPSIS, vegetable production, method

JEL: $Q 12, Q 16$

1 Grujica Vico Ph.D., Assistant Professor, University of East Sarajevo, Faculty of Agriculture, Vuka Karadžića no. 30, 71123 East Sarajevo, B\&H, Phone: +387 65728323 E-mail: vicogrujica@yahoo.com

2 Aleksandra Govedarica Lučić Ph.D., Assistant Professor, University of East Sarajevo, Faculty of Agriculture, Vuka Karadžića 30, 71123 East Sarajevo, B\&H, E-mail: sandraklepic@yahoo.com

3 Zoran Rajić Ph.D., Full Professor, University in Belgrade, Faculty of Agriculture, Nemanjina street no. 6, 11080 Zemun, Serbia, Phone: +381 1126153 15, E-mail: zorajic@agrif.bg.ac.rs

4 Radomir Bodiroga M.A., Ph.D. student, University of East Sarajevo, Faculty of Agriculture, Vuka Karadžića no. 30, 71123 East Sarajevo, B\&H, Phone: +387 65482559 E-mail: radomir.bodiroga@gmail.com

5 Ivan Mičić M.A., Ph.D. student, University in Belgrade, Faculty of Agriculture, Nemanjina street no.6, 11080 Zemun, Serbia, Phone:+381 1126153 15, E-mail: divanlav@gmail.com

6 Dr. sc. Silvija Zec Sambol, Ph.D., Faculty of Medicine, University of Rijeka, Nikole Tesle 1/I, 51000 Rijeka, Croatia, Phone: +381 6286745 98, E-mail: dr.zecss @yahoo.com

7 Marija Mičić M.A., Ph.D. student, University of Niš, Tehnological faculty Leskovac, The Boulevar of Liberation no. 124, 16000 Leskovac, Serbia, Phone: +381 62867 45 98, E-mail: marija84micic@gmail.com

EP 2017 (64) 4 (1355-1364) 


\section{Introduction}

The lettuce falls in the group yellow- green vegetable and is particulary significant in the nutrition due to its rich mineral- vitamin contents, especially during the winter period when there is no sufficient fresh vegetable on the market.

Anyhow, the winter production of lettuce is atributed by insufficient light but also usage of high quanitites of nitrogene mineral manures which results in accumulation of the pestilent nitrate in the lettuce leaves. Accumulation of nitrate largely depends on the fertilizer (especially nitrogen) and climate conditions (Cometi et al., 2011; Proietti et al., 2004; Lazic et al., 2002). Besides nitrates, ascorbic acid concentration is also considered an important quality indicator in lettuces which is also influenced by both abiotic and biotic parameters (Cometti et al., 2011; Llorach et al., 2008). Vitamin C plays multiple roles in the human organism because it increases the organisms resistance to viruses and bacterial infections including allergies (Padayatty et al., 2003).

On the other side, the early fresh vegetable is quite expensive which makes it the most economical vegetable production which provides with planned harvest during the scarce offer on the market. Lettuce is the most popular vegetable according to the highest consumption rate and economic importance throughout the world (Coelho et al., 2005).

Considering the improtance of lettuce in nutrition and its economic justification, it is highly important to apply the corresponding special agro-technical measures in the production of this type. Manufacturing techniques affect growth rate, total yield, earlier yield and yield quality components (El -Shinawy and Gawish, 2006; El-Behairy et al., 2001).

By respecting many economic criteria as well as criteria of nutrition quality in the process of ranking various production technologies, a problem of mutli-criteria decisioning is formed. In solving problems of this type, the most applicable methods are MADM. Numerous (multi-criteria decision making) MCDM methods have been created and utilized over the last several decades (Velasquez and Hester, 2013).

The methods of mutliple attributive decisions is used in a numerous researches in the field of agriculture and similar fileds. The problem spectrum in agriculture where the MADM could be applied is large. SAW method is used for a selection of strategy adaptation in SMEs (Domeova et al., 2006). Authors used 14 products upon three criterias whereas Matejcek and Brozova (2011) applied four types MADM for a selection of the optimal structure of vegetable production. Total of 9 various structures of production are used, 12 criteria and 4 MADM methods (AHP, ORESTE, TOPSIS, WSM). Eventually, the authors come to a compromise solution which took the first ranking in applying the three methods (AHP, TOPSIS, WSM), whereas under fourth method (ORESTE) the variant was placed second. In the literature, there are reseaches with combined methods "hard" and "soft" computing in the process of planning the vegetable production. Matejcek and Brozova (2012) used two types of mathematical model for multi-objective planning: multi-objective linear programming and multiple attribute analysis of variants. In first research stage they used multi-objective simplex algorithm with nine variables, twenty three constraints and 
three criteria. In the second stage, for the process of choosing compromised variants, four multiple attribute analysis methods were used (AHP, ORESTE, TOPSIS, WSM). The combining multi-criteria decision-making methods can provide a whole new approach to decision analysis (Velasquez and Hester, 2013).SAW and Topsis methods, in combination with CP are applied for ranking a tractor (Blagojevic, et al., 2012). Within the paper, a final matrix is created, where the three methods are cited to be used as criteria. SAW is one of the most popular and most used MADM methods in certain research (Ginevicius, 2004, 2008, Ustinovicius, 2004, Vico at al., 2017).

\section{Material and Methods}

Raw data from the experimental greenhouse at the Faculty of Agriculture, University of East Sarajevo were used for ranking four different types of growing technology of winter lettuce. For this research, data from one experiment with three genotipes and four types of technology were used (for more information about this trial see Govedarica-Lucic et al., 2014). During the experiment, data was carefully collected in terms of: mechanization and labour force use, seed, fertilizers, rest of operating supplies, yield. For this research profit calculations were created for each one of the four certain technologies. Four certain growing technologies for production of winter lettuce for genotype SANTORO RZ were used as different alterantives. The trial included four variants of soil covering: control - planting on bare soil - A1, mulching before planting with PE - black foil - A2, agro textile - covering plants after planting with agro textile (17 g) - A3, a combination of mulching + agro textile - A4. Seven different criteria were used for this research (Table 1). Two groups of criteria were used: economic indicators and nutritional quality indicators. Four economic indicators were involved: $\mathrm{C} 1$. revenue as the difference betwen total income and total costs of production (except costs of labour force); C2. profit as difference betwen total income and total cost of production; $\mathrm{C} 3$. profitability as ratio between total income/total costs; C4. labour productivity as ratio between total ammount of products / total ammount of used labour hours. Three nutritional idnicators were used: $\mathrm{C} 5$. contents of vitamin $\mathrm{C}$ (mg/100 g FW); C6. contents of nitrate (g/kg FW); C7. contents of total nitrogen (\%). The alternatives were ranked through two MADM method: SAW and TOPSIS.

\section{Results and Discussion}

In general, every problem of multi-criteria analyses can be solved based upon three approaches: 1. problem in ranking- with intention to rank the group of alternatives 2. problem due to selection of one alternative- only one alternative is chosen from the group - ,the best“ 3 . problem due to selection of many alternatives - a sub-group fom the group of alternatives is chosen. According to this approach, the number of alternatives could be determined in advance, but some conditions can also be set for each separate alternative to accomplish in order to be chosen. In this research, the approach according to which all the alternatives are ranked for application of the two MADM methods: SAW and TOPSIS is chosen. 


\section{The SAW method}

The SAW is one of the simplest, most widely used multi-criteria evaluation method and the most popular MADM method (Polednikova, 2014). This method requires from the decision maker to allocate weight coefficients upon the applied criteria. SAW method is particulary beneficial when all the criteria are numeric values, like the financial indicators. SAW method consists of few main steps. The gerenal form of SAW method is:

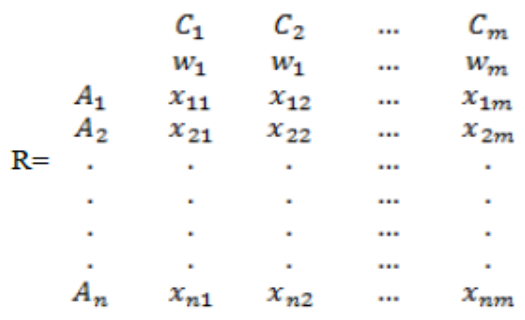

where:

$A_{n}-$ alternatives (certain types of growing technologies)

$\mathrm{C}_{\mathrm{n}}$ - criteria (seven economic and nutritient quality indicators)

$\mathrm{w}_{\mathrm{m}}$ - weight coefficients for criteria

$\mathrm{x}_{\mathrm{ij}}$ - original values

The normalization of criteria is made as following:

For criteria which are maximized: $r_{i j}=\frac{x_{i j}-x_{j}^{* *}}{x_{j}^{*}-x_{j}^{*}}$

For criteria which are minimized: $r_{i j}=\frac{x_{j}^{*}-x_{i j}}{x_{j}^{*}-x_{j}^{*}}$

where $x_{j}^{*}$ is the best value of chosen criteria for all alternatives and $x_{j}^{* *}$ is the worst value.

In the next step normalized matrix is multiplied by the vector of weight coefficients:

$$
\left[\begin{array}{cccc}
r_{11} & r_{12} & \ldots & r_{1 m} \\
r_{21} & r_{22} & \ldots & r_{2 m} \\
\cdot & \cdot & \cdot & \cdot \\
\cdot & \cdot & \cdot & \cdot \\
\cdot & \cdot & \cdot & \cdot \\
r_{n 1} & r_{n 2} & \ldots & r_{n m}
\end{array}\right] *\left[\begin{array}{c}
w_{1} \\
w_{2} \\
\cdot \\
\cdot \\
\cdot \\
w_{m}
\end{array}\right]
$$

and the final value is calculated through:

$S_{i}=\sum_{j=1}^{m} w_{j} r_{i j}$

The best alternative is of the biggest value. 


\section{TOPSIS method}

The TOPSIS method ranks the alternatives according to their distances from the ideal and the negative ideal solution. This method was first developed by Hwang and Yoon (Hwang and Yoon, 1981). Matejcek and Brozova (2011) present four steps within TOPSIS algorithm (according Hwang \& Yoon, 1981) . The steps are: 1. ,the ideal solution is formed as a composite of the best performance values exhibited (in the decision matrix) by any alternative for each attribute. The negative-ideal solution is the composite of the worst performance values. 2. Proximity to each of variants to ideal and negative ideal solution is measured in the Euclidean sense (e.g., square root of the sum of the squared distances along each axis in the "attribute space"), with optional weighting of each attribute. 3. Relative closeness of variants to the ideal solution is defined as the ratio of distance from negative ideal solution and sum of distance from ideal and distance from negative-ideal solution. 4. Selection of the best variant is based on the highest relative closeness.“

The procedure of solving problems through multi-criteria ranking by applying the TOPSIS method via six steps are given in Opricovic and Tzeng (2004):

1. „Calculate the normalized decision matrix.

$r_{i j}=f_{i j} / \sqrt{\sum_{j=1}^{J} f_{i j}^{2}}$

where: $\mathrm{r}_{\mathrm{ij}}$ - normalized values; $\mathrm{j}=1, \ldots, \mathrm{J} ; \mathrm{i}=1 \ldots, \mathrm{n}$

2. Calculate the weighted normalized decision matrix. $v_{i j}=w_{i} r_{i j}$

where $v_{i j}$ weighted normalized values; $v_{i j}$ is weight of the ith attribute. $\mathrm{j}=1, \ldots, \mathrm{J}$; $\mathrm{i}=1 \ldots, \mathrm{n}$.

3. Determine the ideal and negative-ideal solutions.

$$
\begin{aligned}
& A^{*}=\left\{v_{1}^{*}, \ldots, v_{n}^{*}\right\}=\left\{\left(\max _{j} v_{i j} \mid i \in I^{\prime}\right),\left(\min _{j} v_{i j} \mid i \in I^{\prime \prime}\right)\right\} \\
& A^{-}=\left\{v_{1}^{-}, \ldots, v_{n}^{-}\right\}=\left\{\left(\min _{j} v_{i j} \mid i \in I^{\prime}\right),\left(\max _{j} v_{i j} \mid i \in I^{\prime \prime}\right)\right\}
\end{aligned}
$$

Where $I^{\prime}$ is associated with benefit criteria, and $I^{\prime \prime}$ is associated with cost criteria.

4. Through n-dimenzional Euclidean distance calculate the separation of each alternative from the ideal solution: 


$$
D_{j}^{*}=\sqrt{\sum_{i=1}^{n}\left(v_{i j-v_{j}^{*}}\right)^{2}}, j=1, \ldots, J
$$

The separation from the negative ideal solution is given as

$$
D_{j}^{-}=\sqrt{\sum_{i=1}^{n}\left(v_{i j-v_{j}^{-}}\right)^{2}}, j=1, \ldots, J
$$

5. Calculate the relative closeness to the ideal solution. The relative closeness of the alternative $a_{j}$ with respect to $A^{*}$ is defined as

$C_{j}^{*}=\frac{D_{j}^{-}}{\left(D_{j}^{*}+D_{j}^{-}\right)}, \quad j=1, \ldots, J$

6. Rank the preference order.“

\section{Ranking alternatives}

For ranking certain grow technologies SAW and TOPSIS MADM methods were used. Four alternatives and seven criteria were used. The characteristics of criteria are shown in Table 1. Five criteria should be maximized and two criteria should be minimized. All criteria are quantitative values.

Table 1. Specification of criteria

\begin{tabular}{|c|c|c|c|c|}
\hline Criteria & Unit & Criteria group & to be max & to be min \\
\hline $\mathrm{C} 1$ & $\mathrm{BAM} / \mathrm{kg}$ & Economical & + & \\
\hline $\mathrm{C} 2$ & $\mathrm{BAM} / \mathrm{kg}$ & Economical & + & \\
\hline $\mathrm{C} 3$ & $\mathrm{n} / \mathrm{a}$ & Economical & + & \\
\hline $\mathrm{C} 4$ & $\mathrm{n} / \mathrm{a}$ & Economical & + & \\
\hline $\mathrm{C} 5$ & $\mathrm{mg} / 100 \mathrm{~g} \mathrm{FW}$ & Quality & + & \\
\hline $\mathrm{C} 6$ & $\mathrm{~g} / \mathrm{kg} \mathrm{FW}$ & Quality & & + \\
\hline $\mathrm{C} 7$ & $\%$ & Quality & & + \\
\hline
\end{tabular}

Source: Work of author

Two economic criteria are absolute values representing effectiveness (revenue and profit), while other two criteria are relative values representing economic efficiency in vegetable production (labour productivity and profitability). 
Table 2. The raw data for certain alternatives

\begin{tabular}{|c|c|c|c|c|c|c|c|}
\hline Alternative & $\begin{array}{c}\text { C1 } \\
\text { (BAM/kg) }\end{array}$ & $\begin{array}{c}\text { C2 } \\
\text { (BAM/kg) }\end{array}$ & $\mathbf{C 3}$ & $\mathbf{C 4}$ & $\begin{array}{c}\mathbf{C 5} \\
(\mathbf{m g} / \mathbf{1 0 0} \mathbf{g} \\
\mathbf{F W})\end{array}$ & $\begin{array}{c}\mathbf{C 6} \\
(\mathbf{g} / \mathbf{k g} \text { FW) }\end{array}$ & $\begin{array}{c}\text { C7 } \\
\text { (\%) }\end{array}$ \\
\hline A1 & 1,80 & 1,15 & 1,63 & 3,90 & 18,65 & 2196,33 & 3,85 \\
\hline A2 & 1,86 & 1,37 & 1,84 & 5,09 & 18,45 & 2412,83 & 3,95 \\
\hline A3 & 1,88 & 1,43 & 1,91 & 5,53 & 27,03 & 2526,24 & 4,07 \\
\hline A4 & 2,12 & 1,75 & 2,39 & 6,76 & 26,79 & 2519,63 & 3,99 \\
\hline
\end{tabular}

Source: Work of author

Ceratin alternatives show differences between values within some criteria. For example, alternative A4 is the best according to the economic criteria, but the worst according C5. Alternative A1 is the worst according to all economic criteria, but it is the best according all nuritional quality criteria.

For unique ranking some MADM methods are needed to be used. Within this research we chose the two most frenquently used methods: SAW and TOPSIS.

Before making the calculation, the weight coefficients must be defined.

Table 3. Weight coefficients for certain models

\begin{tabular}{|c|c|c|c|c|c|c|c|c|c|}
\hline \multirow{2}{*}{ Model } & \multicolumn{4}{|c|}{ Economic criteria } & \multicolumn{4}{|c|}{ Nutritional quality criteria } \\
\cline { 2 - 11 } & $\mathbf{C 1}$ & $\mathbf{C 2}$ & $\mathbf{C 3}$ & $\mathbf{C 4}$ & $\begin{array}{c}\text { Total for } \\
\text { group }\end{array}$ & $\mathbf{C 5}$ & $\mathbf{C 6}$ & $\mathbf{C 7}$ & $\begin{array}{c}\text { Total for } \\
\text { group }\end{array}$ \\
\hline S1 & 0,125 & 0,125 & 0,125 & 0,125 & 0,500 & 0,167 & 0,167 & 0,167 & 0,500 \\
\hline S2 & 0,167 & 0,167 & 0,167 & 0,167 & 0,667 & 0,111 & 0,111 & 0,111 & 0,333 \\
\hline S3 & 0,083 & 0,083 & 0,083 & 0,083 & 0,333 & 0,222 & 0,222 & 0,222 & 0,667 \\
\hline
\end{tabular}

Source: Work of author

In the first scenario (S1) economic criteria and nutritional quality criteria have the same values of weight coefficients, 0,500 for both. The second scenario (S1) favorizes the economic criteria. Economic criteria $(0,667$ vs 0,333 for Nutritional quality criteria). In the third scenario (S1) values are reciprocal (table 3$)$

Table 4. Results of ranking

\begin{tabular}{|c|c|c|c|c|c|c|}
\hline \multicolumn{7}{|c|}{ SAW } \\
\hline \multirow{2}{*}{ Alternative } & \multicolumn{2}{|c|}{ S1 } & \multicolumn{2}{|c|}{ S2 } & \multicolumn{2}{|c|}{$\mathbf{S 3}$} \\
\hline & Value & Order & Value & Order & Value & Order \\
\hline A1 & 0,33722 & 3 & 0,22481 & 4 & 0,44962 & 2 \\
\hline A2 & 0,30402 & 4 & 0,30656 & 3 & 0,30148 & 4 \\
\hline $\mathrm{A} 3$ & 0,37354 & 2 & 0,38695 & 2 & 0,36014 & 3 \\
\hline A4 & 0,72595 & 1 & 0,81730 & 1 & 0,63460 & 1 \\
\hline \multicolumn{7}{|c|}{ TOPSIS } \\
\hline \multirow{2}{*}{ Alternative } & \multicolumn{2}{|c|}{ S1 } & \multicolumn{2}{|c|}{ S2 } & \multicolumn{2}{|c|}{ S3 } \\
\hline & Value & Order & Value & Order & Value & Order \\
\hline A1 & 0,17473 & 4 & 0,10601 & 4 & 0,23930 & 3 \\
\hline A2 & 0,29288 & 3 & 0,33831 & 3 & 0,22204 & 4 \\
\hline A3 & 0,57562 & 2 & 0,51615 & 2 & 0,64900 & 2 \\
\hline A4 & $\mathbf{0 , 8 3 3 9 0}$ & 1 & 0,89969 & 1 & 0,77145 & 1 \\
\hline
\end{tabular}

Source: Work of author 
The type of growing winter lettuce which uses a combination of mulching with agrotextile (A4) is the best alternative (table 4.). The economic parameters of A4 are much higher than every other alternative. The difference between A4 and other alternatives is the lowest in S3 for both SAW and TOPSIS methods. The A4 has high values for C6 and $\mathrm{C}$, which is the poor, but good economic performances are contributing for the best global score. The A2 is a type of growing technology with the worst global score for both metods.

Data in Table 4 shows that SAW method is more sensitive on weight coefficients changes, than TOPSIS method. The used two MADM methods in this research can be good as terminated tools not only in agro-economic research, but also in other studies in the field of agriculture.

\section{Conclusion}

The production of winter lettuse in greenhouses can be realized based on many technologies, upon which various production results are obtained. The choise of the most applicable technology is a process where many attributes should be respected. By applying in that process many economic criteria as well as criteria of nutrition quality, a multi-attribute problem is achieved which could be solved through some of the MADM methods. By applying of SAW and TOPSIS methods a close ranking of the alternatives is obtained. There is a wide spectrum of problems in agricultural production which are in fact a multicriteria task and could be solved by application of some of the MADM methods.

\section{References}

1. Blagojevic, B., Matic-Kekic, S., Ruzic, D., Dedovic, D. (2012). Application of SAW, TOPSIS and CP methods in the tractors ranking based on the ergonomic charasteristics. Contemporary Agricultural Engineering, Vol. 38, No. 4, pp. 287-376.

2. Cometti, N., Martins, M., Bremenkamp, C., Nunes, A. (2011). Nitrate concentration in lettuce leaves depending on photosynthetic photon flux and nitrate concentration in the nutrient solution. Horticulture Brasil, Vol. 29, pp. 548-553.

3. Coelho, A.F.S., Gomes, E.P., Sousa, A.P., Gloria, M.B.A.( 2005). Effect of irrigation level on yield and bioactive amine content of American lettuce. J. Sci. Food. Agric., Vol. 85, pp. 1026-1032.

4. Domeova, L., Houska, M., Berankova, M. (2006). Multiple-criteria approach for strategy adaptation in SME's. Agricultural Economics (Agriecon)- Czech. Czech Academy for Agricultural Sciences, No. 4, pp. 155-159.

5. El-Behairy, U.A., El-Shinawy, M.Z., Medany, M.A., Abou-Hadid, A.F. (2001). Utilization of "A-shape" system of nutrient film technique (NFT) as a method for producing some vegetable crops intensively. Acta Hort., Vol. 559, pp. 581-586.

6. El-Shinawy, M.Z., Gawish, S.M. (2006). Effect of commercial organic nutrient solutions on growth and chemical composition of lettuce under agricultural soilless system. Egypt. J. Hort., Vol. 33, pp. 19-28. 
7. Ginevicius, R., Podvezko, V. (2004). Complex evaluation of the use of information technologies in the countries of Eastern and Central Europe. Journal of Business Economics and Management, Vol. 5. No. 4: pp. 183-191.

8. Ginevicius, R., Podvezko, V. (2008). Daugiakriterinio vertinimo būdų suderinamumas. Business: theory and practice, Vol. 9. No. 1: pp. 73-80.

9. Govedarica-Lucic, A., Mojevic, M., Perkovic, G., Govedarica, B. (2014). Yield and nutrition quality of greenhouse lettuce as affected by genotype and production methods. Genetika, Vol. 46, No.3, pp. 1027-1036.

10. Hwang, C.L., Yoon, K. (1981). Multiple Attribute Decision Making: Methods and Applications, Springer-Verlag, New York.

11. Lazic, B., Markovic, V., Djurovka, M., Ilin, Z. (2002). The influence of biological factors and the quality of production vegetable. Food and nutrition, Vol. 43, No. 3-6, pp. 135-137.

12. Llorach, R., Martinez-Sanchez, A., Tomas-Barberan F.A., (2008). Characterisation of polyphenols and antioxidant properties of five letuce varieties and ascarole. Fod Chemistry A Vol. 108, pp. 1028-1038.

13. Matejcek, M., Brozova, H. (2011). Multiple attributes analysis of vegetable production. Mathematics and Computers in Biology, Business and Acoustics. Transilvania University of Brasov, Romania, pp. 27-33.

14. Matejcek, M., Brozova, H. (2012). Multi-objective planning of vegetable production. Scientia agriculturae bohemica, 43. Czech University of Life Sciences Prague, No. 1, pp. 28-38.

15. Opricovic, S., Tzeng, G.H. (2004). Compromise solution by MCDM methods: A comparative analysis of VIKOR and TOPSIS. European Journal of Operational Research, 156, Vol. 156, pp. 445-455.

16. Padayatty, S.J., Katz, A., Wang, Y., Eck, P., Kwon, O., Lee, J.H., Chen, S., Corpe, C., Dutta, A., Dutta, S.K., Levine, M. (2003). Vitamin C as an antioxidant: evaluation of its role in disease prevention. Journal of the American College of Nutrition, Vol. 22, No. 1, pp. 18-35.

17. Polednikova, E. (2014). Comparing Regions' Ranking by MCDM methods: the Case of Visegrad Countries. Wseas transactions on business and economics, Vol. 14, pp. 496-507.

18. Proietti, S., Moscatello, S., Leccese, A., Colla, G., Battistelli, A. (2004). The effect of growing spinach (Spinacia oleracea L.) at two on the amounts of oxalate, ascorbate and nitrate in their leaves. Journal Horticulturae Science Biotechnology Vol. 79, No. 4, pp. 606-609.

19. Ustinovicius, L., Sarkiene, E., Sarka, V. (2003). Individualių namu architektūriniu sprendimų modelis, taikant daugiakriterinius sintezès metodus. Technological and Economic Development of Economy, Vol. 9. No. 1: pp. 18-26.

20. Velasquez, M., Hester, T.P. (2013). An Analysis of Multi-Criteria Decision Making 
Methods. International Journal of Operations Research, 66-Vol. 10, No. 2, 56.

21. Vico, G., Mijić, D., Bodiroga, R. (2017): Dvofazni pristup višekriterijumskom odlučivanju u biljnoj proizvodnji. Zbornik radova, XXII savjetovanje o biotehnologiji, Čačak, 1, Vol. 1, pp. 413-417.

\title{
PRISTUP VIŠEATRIBUTIVNE PROCENE U PROIZVODNJI POVRĆA
}

\author{
Grujica Vico $^{8}$, Aleksandra Govedarica-Lučič ${ }^{9}$, Zoran Rajićc ${ }^{10}$, Radomir Bodiroga ${ }^{11}$, \\ Ivan Mičićc ${ }^{12}$ Silvija Zec Sambol ${ }^{13}$, Marija Mičićc ${ }^{14}$
}

\begin{abstract}
Sažetak
U radu je korišćeno dvije vrste kriterijuma ekonomske efektivnosti $i$ dvije vrste kriterijuma ekonomske efikasnosti, kao i tri indikatora nutritivnog kvaliteta za rangiranje različitih tehnologija gajenja zimske salate. Korišćenjem dvije metode višeatributivnog odlučivanja, izvršeno je rangiranje četiri različite tehnologije gajenja zimske salate u zaštićenom prostoru. Prikazani su rezultati rangiranja na osnovu oba korišćena metoda, SAW i TOPSIS. Alternative su rangirane kroz tri scenarija koji se razlikuju po težinskim koeficijentima. Tehnologija proizvodnje koja podrazumjeva malč+agrotekstil pokazala se kao najbolja alternativa pri korišćenju oba metoda i svih scenarija. SAW metod se pokazao kao senzitivniji na promjene težinskih koeficijenata u odnosu na TOPSIS metod.
\end{abstract}

Ključne reči: višeatributivno odlučivanje, SAW, TOPSIS, proizvodnja povrća, metod

8 Doc. Dr Grujica Vico, Univerzitet u Istočnom Sarajevu, Poljoprivredni fakultet, Vuka Karadžića br. 30, 71123 Istočno Sarajevo, BiH, Telefon: +387 57340 401, E-mail: vicogrujica@yahoo.com

9 Doc. Dr Aleksandra Govedarica Lučić, Univerzitet u Istočnom Sarajevu, Poljoprivredni fakultet, Vuka Karadžića br. 30, 71123 Istočno Sarajevo, BiH, Telefon: +387 57340 401, E-mail: sandraklepic@yahoo.com

10 Redovni profesor, dr Zoran Rajić, Univerzitet u Beogradu, Poljoprivredni fakultet, Nemanjina ulica br. 6, 11080 Zemun, Srbija, Telefon: +381 1126153 15, E-mail: zorajic@agrif.bg.ac.rs

11 Mr Radomir Bodiroga, doktorant, Univerzitet u Istočnom Sarajevu, Poljoprivredni fakultet, Vuka Karadžića br. 30, 71123 Istočno Sarajevo, BiH, Telefon: +387 55250122 E-mail: radomir.bodiroga@gmail.com

12 Mr Ivan Mičić, doktorant, Univerzitet u Beogradu, Poljoprivredni fakultet, Nemanjina ulica br. 6, 11080 Zemun, Srbija, Telefon: +381 6297311 58, E-mail: divanlav@gmail.com

13 Dr. sc. Silvija Zec Sambol, dr med. Medicinski fakultet Sveučilišta u Rijeci, Nikole Tesle 1/I, 51000 Rijeka, Croatia, Telefon: +381 6286745 98, E-mail: dr.zecss @yahoo.com

14 Mr Marija Mičić, doktorant, Univerzitet u Nišu, Tehnološki fakultet u Leskovcu, Bulevar Oslobođenja br. 124, 16000 Leskovac, Srbija, Telefon: +381 6286745 98, E-mail: marija84micic@gmail.com 
ECONOMICS OF

AGRICULTURE

\section{CONTENT}

1. Adriana Radosavac, Desimir Knežević

ECONOMIC IMPORTANCE OF USE

OF PESTICIDES IN WHEAT PRODUCTION . . . . . . . . . . . 1323

2. Berhe Gebregewergs, Muuz Hadush

DOES CLIMATE CHANGE AFFECT PRICE OF VEGETABLES:

EVIDENCE FROM TIGRAI, NORTHERN MOST ETHIOPIA. . . . .1335

3. Grujica Vico, Aleksandra Govedarica-Lučić, Zoran Rajić, Radomir Bodiroga, Ivan Mičić, Silvija Zec Sambol, Marija Mičić

MULTI ATTRIBUTE ASSESSMENT APPROACH

IN VEGETABLE PRODUCTION . . . . . . . . . . . . . . 1355

4. Igor Trandafilović, Vesna Conić, Aleksandra Blagojević

IMPACT OF DEMOGRAPHIC FACTORS ON

ENVIRONMENTALLY CONSCIOUS PURCHASE BEHAVIOUR. . .1365

5. Imre Milán Harcsa

STUDY ON THE POTENTIAL OF SUBCONTRACT

PALINKA DISTILLATION . . . . . . . . . . . . . . 1379

6. Jelena Andrašić, Vera Mirović, Nada Milenković, Branimir Kalaš, Miloš Pjanić

IMPACT OF TAKEOVER PROCESS ON EMPLOYEES -

EVIDENCE FROM FOOD, RETAIL AND FINANCIAL SECTOR . . .1393

7. Jelena Birovljev, Danilo Đokić, Bojan Matkovski, Žana Kleut

ECONOMIC PERFORMANCES OF AGRICULTURE

OF CEFTA AND FORMER CEFTA COUNTRIES . . . . . . . . . . 1413

8. Jelena Marković, Svetlana Stevović

SUSTAINABILITY OF CHEMICAL SOIL QUALITY

IN SOUTHERN MORAVA RIVER VALLEY

IN CORELLATION WITH THE FLOODING $\ldots \ldots \ldots \ldots \ldots$ 
9. Mile Peševski, Zoran Milovančević

THE CHANGES IN THE USAGE OF AGRICULTURAL LAND

IN EASTERN REGION OF REPUBLIC OF MACEDONIA

BETWEEN $1991-2030 \ldots \ldots$. . . . . . . . . . . . . . . . . . . . . . .

10. Odjuvwuederhie Emmanuel Inoni, 'Oraye Dicta Ogisi, Felix Odemero Achoja

PROFITABILITY AND TECHNICAL EFFICIENCY IN HOMESTEAD

CATFISH PRODUCTION IN DELTA STATE, NIGERIA . . . . . . . 1449

11. Olja Munitlak - Ivanović, Jovan Zubović, Petar Mitić

RELATIONSHIP BETWEEN SUSTAINABLE DEVELOPMENT AND

GREEN ECONOMY - EMPHASIS ON GREEN FINANCE

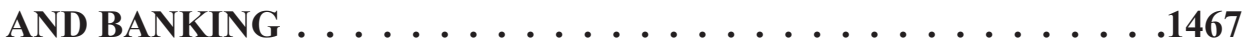

12. Petar Munćan, Dragica Božić

FARM SIZE AS A FACTOR OF EMLOYMENT AND INCOME

OF MEMBERS OF FAMILY FARMS . . . . . . . . . . . . . 1483

13. Rade Popović, Mira Kovljenić

EFFICIENCY OF WHEAT PRODUCTION ON FARMS

IN THE REPUBLIC OF SERBIA . . . . . . . . . . . . . . . . . . . . . . . . .

14. Radovan Damnjanović, Snežana Krstić, Milena Knežević, Svetislav Stanković,

Dejan Jeremić

THE DISCRIMINANT ANALYSIS APPLIED TO THE

DIFFERENTIATION OF SOIL TYPES . . . . . . . . . . . . 1513

15. Slavica Otović, Dunja Demirović, Kristina Košić, Aleksandra Vujko

FOSTERING ENTERPRENUERSHIP AT HIGH SCHOOLS:

A CASE OF RURAL AREAS IN VOJVODINA (SERBIA) . . . . . . .1523

16. Vladimir Ilić, Ivan Bauer, Anastazija Tanja Đelić, Aleksandar Nešković

INSTITUTIONAL SUPPORT FOR STRENGTHENING

ENTREPRENEURSHIP IN AGRICULTURAL PRODUCTION

OF THE REPUBLIC OF SERBIA . . . . . . . . . . . . . . . . . . . . . . . .

17. Boro Krstić, Zorica Vasiljević, Miroslav Nedeljković

INSURANCE CONTRACT AS THE BASIS FOR THE SAFETY OF

AGRICULTURAL PRODUCERS IN THE REPUBLIC OF SRPSKA • . 1555

18. Dejan Sekulić, Aleksandar Petrović, Vladimir Dimitrijević

WHO ARE WINE TOURISTS? AN EMPIRICAL INVESTIGATION

OF SEGMENTS IN SERBIAN WINE TOURISM . . . . . . . . . . . . . 
19. Milan Beslać, Ćorić Goran

FINANCIAL AND PRODUCTION ASPECTS OF GENETICALLY MODIFIED ORGANISMS $\ldots \ldots \ldots \ldots \ldots \ldots \ldots \ldots \ldots$

20. Mlađan Maksimović, Darjan Karabašević, Miodrag Brzaković, Pavle Brzaković THE EFFECTS RESULTING FROM THE APPLICATION OF THE CONCEPT OF THE SUSTAINABLE DEVELOPMENT OF RURAL TOURISM ON STARA PLANINA . . . . . . . . . . . . . . . .1595

21. Vesna Popović, Predrag Vuković, Milivoje Ćosić FOOD SAFETY AND QUALITY POLICY IN THE REPUBLIC OF SERBIA . . . . . . . . . . . . . . . . 1607

22. Radovan Pejanović, Danica Glavaš-Trbić, Mirela Tomaš-Simin PROBLEMS OF AGRICULTURAL AND RURAL DEVELOPMENT IN SERBIA AND NECESSITY OF NEW AGRICULTURAL POLICY . . . .1619

23. Saša Marković, Slavoljub Vujović, Aleksandar Damnjanović MARKETING AND HIGHER EDUCATION CONDITION IN SERBIA . . . . . . . . . . . . . . . . 1635

24. Semir Vehapi, Marina Milanović THE EFFECT OF MARKET ORIENTATION ON BUSINESS PERFORMANCE OF SERBIAN ORGANIC PRODUCERS . . . . . 1651

25. Suad Bećirović, Šemsudin Plojović, Enis Ujkanović, Senadin Plojović CHALLENGES AT STARTING AN AGRIBUSINESS IN THE HILLY MOUNTAINOUS REGIONS OF SOUTHWEST SERBIA . . . . . . . .1669

26. Vladimir Zakić, Vlado Kovačević, Jelena Damnjanović SIGNIFICANCE OF FINACIAL LITERACY FOR THE AGRICULTURAL HOLDINGS IN SERBIA . . . . . . . . . . 1687

27. Željko Bjelajac, Marijana Dukić Mijatović, Željko Vojinović PROTECTION OF LAND IN THE REPUBLIC OF SERBIA AND ECOLOGICAL SECURITY WITH REGARD TO STRATEGIC AND LEGAL FRAMEWORKS . . . . . . . . . .1703 